\title{
Unpleasant Emotions in Linking Cognitive Appraisals and Academic Procrastination in Doing Thesis Article: A Perspective of Control-Value Theory
}

\author{
$1^{\text {st }} \mathrm{R} \mathrm{D}$ Agustiningsih \\ Psychology Program, Faculty of Social and Humaniora \\ Universitas Muhammadiyah Bandung \\ Soekarno-Hatta Street 752, Indonesia \\ rikadwia@umbandung.ac.id
}

\begin{abstract}
The objective the present study was to investigate the relationships among cognitive appraisals (selfefficacy, value, and causal attribution), unpleasant emotions (anxiety, anger, boredom, and hopeless), and academic procrastination (intention-behavior discrepancy, lack of promptness, and preferences in choosing activities) in college student while they were doing thesis. More specifically, the study investigated the mediating role of unpleasant emotions in linking cognitive appraisals and procrastination in doing thesis from the perspective of the expectancy-value theory. A total of 128 college students completed a self-reported survey for the study. The results of the study showed that unpleasant emotions influencing procrastination in doing thesis is anxiety, which was also influenced by cognitive appraisals, self-efficacy particularly. Based on the findings of the current research, it seemed that to increase perseverance and engagement in doing thesis could be done by increasing the efficacy of students so that it will reduce anxiety.
\end{abstract}

Keywords-emotions, Linking Cognitive, Procrastination, Value Theory

\section{INTRODUCTION}

Thesis article is a scientific paper, in the form of exposure the results of research that discusses a problem in a particular field of science using scientific principles that are applying in a particular field of science (Pedoman Penyusunan dan Penulisan Skripsi Program Sarjana Universitas Padjadjaran, 2011). Final-year students have the obligation to do their thesis or final project as a prerequisite in completing Bachelor Program studies. The number of activities in the work of thesis article, such as writing, reading, understanding concepts, studying, taking data, discussing problems, research discussions, discussing with supervisor (lecturer). The number of activities carried out in thesis research makes students choose whether he wants to finish their thesis or delay the completion of it.

Delays to an activity by some experts are known as procrastination (Steel, 2007; Burka and Yuen, 1983; Ferrari, Johnson and McCown, 1995; Knaus, 1998). Steel (2007) explains that procrastination is delaying the commencement or completion of a planned behavior or delay of decision making. Procrastination in the context of working on thesis article means that students postpone or do not do thesis article activities in accordance with the specified time. This is accompanied by the emergence of unpleasant emotions. Similarly, it can be said that, academic procrastination behavior is to postpone academic duties in a way that that is causes failure, academic unhappiness and stress. Those unpleasant emotions are influenced by the appraisal of their abilities and demands of the thesis that make students bring up different emotions.

How important mental health is in student academic achievement, thus the purpose of this study is to determine predictors of procrastination mediated by the certain emotions.

\section{THEORETICAL FRAMEWORK}

Procrastination is the behavior of postponing tasks (Burka \& Yuen, 1983). Academic procrastination is the behavior of avoiding academic demands that cause academic failures. Many studies have shown that students who carry out academic procrastination face various unpleasant impacts from their behavior (Burka and Yuen, 1983; Kandemir, 2010). Procrastination manifests into three behaviors: lack of promptness, intention-behavior discrepancy, and preference for competing activities (Schouwenburg, 1995).

Procrastination in thesis-article work is postponing of all activities in doing thesis article, causing the delay of graduation doesn't even pass. While working on thesis article, students are influenced by various emotions that have an impact on delays in thesis work. Numerous studies have shown that the impact of procrastination on emotional discomfort; increased anxiety, decreased expectations, and low performance in schools and workplaces (Alexander \& Onwuegbuzie, 2007; Jackson, Weiss, Lundquist, \& Hooper, 2003; Onwuegbuzie, 2000; Solomon \& Rothblum, 1984). Pekrun and Linnenbrink-Gracia (2012) explain that 
in every learning activities are always accompanied by emotions, both positive and unpleasant emotions.

In the theory of control-value theory of achievement emotions explained that emotions are a key predictor of learning activities (King \& Gaerlan, 2014; Pekrun, 2006, 2009), which can support or hinder students' academic achievement (Pekrun \& Linnenbrink-Gracia, 2012). Emotions emerge when students feel they can control or not the activities and academic outcomes that are important to them (Goetz, Frenzel, Stieger, \& Hall, 2010, in Pekrun \& Linnenbrink-Gracia, 2012). The concept of control-value theory of achievement emotions integrates several psychological variables that explain the role of subjective control and subjective value (cognitive appraisals) on achievement emotions which influence student achievement (Pekrun et al., 2006). Thus, emotions are assumed as mediators between cognitive appraisals and procrastination on thesis work activities. Pekrun and Linnenbrink-Gracia (2012) expand this theoretical framework to explain the uniqueness of the emotional correlation with learning activities, one of which is procrastination. These emotions emerge because of the interaction that occurs between control and value appraisals. Different combinations of the two produce different types of emotions (Pekrun, 2007). Pekrun et al. (2002) explains that there are nine emotions that influence students in their academic activities. However, many studies have showed that only negative emotions affected procrastination behavior, those are anger, anxiety, hopelessness, and boredom.

Anger emerges when a student feels that thesis is an academic task that must be done with a feeling of being forced, accompanied by attribution to others when activities or the results of the thesis are not accordance with his expectations. Anxiety arises when a student feels that a thesis is a valuable thing so it is important for him to be able to finish it, but he has doubts about his ability to undergo thesis work activities, students becoming fear of failure. Hopelessness are experienced when cognition focuses on the inability to achieve success in thesis article but focuses more on the inability to avoid failure. Lastly, when students do not appraise their thesis positively or negatively, students appraise that thesis is an easy thing to do, must be done routinely, and lacks challenges, boredom will arise. If students appraise the thesis article to have demands that are beyond their ability and are difficult to work on, this will also have an impact on feeling bored. The emergence of negative emotions in students working on thesis can reduce the interest in thesis work activities (Turner and Waugh, 2007). Based on explanation above, negative cognitive appraisals will emerge negative emotions that can affect procrastination in thesis work.

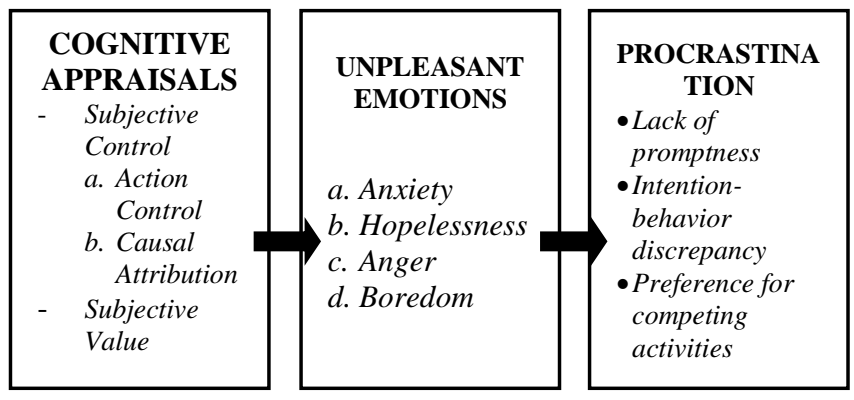

Fig. 1. Research Conceptual Framework

\section{METHOD}

\section{A. Participants}

The research participants were 128 final year students, who were contracting thesis article courses. Convenience sampling was used as sampling technique, which is a nonprobability sampling method whereby the sample of participants selected is based on convenience and includes individuals who are readily available (Christensen, 2011).

$B$. Variable and measures

The research variables will be measured using questionnaires (self-report).

1. Cognitive appraisals

Cognitive appraisals consist of two aspects:

- Subjective control: refers to appraisal of control over actions and outcomes (controllability), whereby such control can be exerted by oneself or external factors (agency) (Pekrun \& Garcia, 2014). Appraisals of control included actioncontrol expectancies whether one is able to successfully initiate and perform an action
(Pekrun \& Garcia, 2014), and causal attribution involves linking given effects to possible causes (Weiner, 1985)

- $\quad$ Subjective value: involves both perceived degree of importance for oneself (goal relevance) and perceived direction (positive versus negative) (Pekrun \& Garcia, 2014).

Cognitive appraisals is measured using the Cognitive Appraisals Questionnaire in Thesis Work that measures two aspects: subjective control, including action control (n $=4$ items; $\alpha=0.663)$ and causal attribution $(\mathrm{n}=2$ items; $\alpha$ $=0.746)$; and subjective value $(\mathrm{n}=8$ items; $\alpha=0.785)$. This questionnaire using five-point Likert scale choices (from 1 $=$ totally disagree $/$ not all influential, to $5=$ totally agree).

\section{Emotions}

Achievement emotions defined as emotions tied directly to achievement activities or achievement outcomes (Pekrun, 2006). Unpleasant Emotions Questionnaire in Thesis Work consists of 4 (four) unpleasant emotions $(\alpha=0.945)$, which includes anxiety $(\mathrm{n}=9$ items; $\alpha=0.860)$, boredom $(\mathrm{n}=6$ items; $\alpha=0.858)$, anger ( $\mathrm{n}=8$ items; $\alpha=0.892)$, and 
hopeless ( $\mathrm{n}=8$ items; $\alpha=0.852)$. This questionnaire using five-point Likert scale choices (from $1=$ not appropriate, up to $5=$ really appropriate)

3. Procrastination

Procrastination is the behavior of postponing tasks (Burka $\&$ Yuen, 1983). The total items on the Procrastination in Thesis Work Questionnaire $(\alpha=0.872)$ are 11 items. This questionnaire using five-point Likert scale choices (from 1 $=$ not appropriate, up to $5=$ really appropriate).

C. Statictical analysis

The data were analyzed using multiple regression to measure the predictors of cognitive appraisals to procrastination in thesis work activities mediated by unpleasant emotions.

\section{FINDINGS}

A. Effect of cognitive appraisals on procrastination by emotions as mediator variable

The research found that the effect of cognitive appraisals on procrastination do not have a direct effect. The effect of cognitive appraisals on academic procrastination needs to be mediated by unpleasant emotional variables (Effect $=0.2576)$. The emotions variable has a role in determining the emergence of procrastination. The negative cognitive appraisals of the thesis work activity emerge unpleasant emotions. They affect on delaying the completion of thesis.

TABLE I. SUMMARY OF MEDIATION TEST RESULTS FOR THE COGNITIVE APPRAISALS VARIABLES ON PROCRASTINATION WITH AND WITHOUT NEGATIVE EMOTIONS.

\begin{tabular}{|c|c|c|c|c|c|c|}
\hline \multirow{2}{*}{ Path } & \multicolumn{2}{|c|}{ Without Unpleasant Emotions } & \multicolumn{2}{c|}{ With Unpleasant Emotions as Mediator } \\
\cline { 2 - 7 } & $\mathbf{d}$ & $\mathbf{t}$ & Sig. & d & t & Sig. \\
\hline Cognitive Appraisals $\rightarrow$ Procrastination & 0.0538 & 0.5822 & 0.5614 & 0.2576 & 2.7663 & 0.0065 \\
\hline
\end{tabular}

\section{B. Predictors of unpleasant emotions to procrastination}

The results of this study indicate that the unpleasant emotions that most influence the students' procrastination in doing thesis is anxiety (see Table II.). The level of determination of anxiety to procrastination is moderate, other factors influencing procrastination in thesis work. While other unpleasant emotions do not show a significant effect on this procrastination.

TABLE II. PREDICTORS OF UNPLEASANT EMOTIONS ON PROCRASTINATION.

\begin{tabular}{|l|c|c|c|c|c|}
\hline \multicolumn{1}{|c|}{ Unpleasant Emotions } & Coefficient & $\mathbf{t}$ & $\mathbf{R}^{\mathbf{2}}$ & Sig. & Desc. \\
\hline Anxiety & 0.551 & 5.875 & 0.308 & 0.000 & Moderate \\
\hline Boredom & 0.306 & 3.027 & 0.147 & 0.003 & Weak \\
\hline Anger & 0.153 & -1.649 & 0.092 & 0.102 & Weak \\
\hline Hopeless & 0.170 & 0.002 & 0.125 & 0.987 & Weak \\
\hline
\end{tabular}

Note: * Significant at the error level of 0.05 if the value of t obtained is greater than 1.96

$\mathrm{R}^{2}$ value $\leq 0.19$ (weak), $0.20-0.66$ (moderate), $\geq 0.67$ (strong)

\section{Predictors of cognitive appraisals to unpleasant} emotion (anxiety)

In the next step, as shown in Table III subjective control, especially action control (self-efficacy) has the

TABLE III. THE EFFECT OF COGNITIVE APPRAISALS ON ANXIETY

\begin{tabular}{|c|c|c|c|c|c|}
\hline Cognitive Appraisals & Coefficient & $\mathbf{t}$ & $\mathbf{R}^{\mathbf{2}}$ & Sig. & Desc. \\
\hline Action Control & -0.444 & -4.650 & 0.216 & 0.000 & Moderate \\
\hline Attribution & 0.119 & 1.470 & 0.000 & 0.144 & Weak \\
\hline Value & -0.079 & -0.823 & 0.091 & 0.412 & Weak \\
\hline
\end{tabular}

Note: * Significant at the error level of 0.05 if the value of t obtained is greater than 1.96

$\mathrm{R}^{2}$ value $\leq 0.19$ (weak), $0.20-0.66$ (moderate), $\geq 0.67$ (strong)

\section{DISCUSSION}

Burka and Yuen (1983) define procrastination as the behavior of postponing tasks. Academic procrastination is a form of procrastination specific to academic settings. It involves knowing that one needs to carry out an academic task or undertake an academic activity, but, for one reason or another, failing to motivate oneself to do so within the expected time frame. Students who do procrastination of their thesis, will not succeed in finishing thesis on time, there is a discrepancy between intention and behavior in working on the thesis, and will choose other activities compared to working on thesis. Students with high levels of procrastination in the thesis work activities showed a low level of student involvement in thesis work, especially in exerting their effort and focus to graduate on time. most negative effect on anxiety. The low level of confidence in the ability to do their thesis has an impact on the emergence of anxiety during thesis work.
The long process in thesis work makes it difficult for students to stay focused and persevere on it. Students choose to do other activities, the commitment to do the thesis becomes diverted. In addition, it is difficult to maintain a commitment to work on a thesis, easily distracted so that there is a gap between the initial intention and the effort that is deployed. Students become not optimal in searching or reading literature, writing thesis, and discussing with friends related to thesis.

Pekrun and Linnenbrink-Gracia (2012) explain that emotions become antecedents of the components of learning activities with cognitive appraisals. In several studies found that emotion affects cognitive processes that contribute to the learning process, such as perception, attention, social appraisal, problem solving, decision making, and memory processes (Clore \& Huntsinger, 2007, 
2009; Loewenstein \& Lerner, 2003; Parrott \& Spackman, 2000 , in Pekrun \& Linnenbrink-Gracia, 2012). The results showed that student procrastination in thesis work was influenced by action control, causal attribution, and value mediated by unpleasant emotions, especially anxiety.

Student who was overwhelmed with anxiety will affect the student's thought process which becomes irrelevant to the thesis supervision process. Students have important value perceptions towards the thesis article but not accompanied by a high level of control that will cause anxiety when meeting with the supervisor, he will produce thoughts that are not relevant to the task (Eysenck, 1997; Wine, 1971; Zeidner, 1998) so he hasn't thought anything about supervision process. In this study, it was seen that high anxiety in thesis work, decreasing commitment and effort of students when doing thesis. Low anxiety will make students think rationally and focus in exerting their efforts to do their thesis.

Anxiety in thesis work emerges because of the cognitive appraisals towards the thesis task that is formed due to environmental factors. Cognitive appraisals do not directly influence student involvement. However, cognitive appraisals will produce certain emotions and ultimately have an impact on student learning activities, whether students will commit to do their thesis or not.

Cognitive appraisals resulted from students' personal beliefs about abilities that are influenced by student appraisals of the demands in the thesis. It makes students appraise the extent of control over their ability to work on thesis, and assesses the extent of the priority of the thesis to do at this time. Cognitive appraisals determine the quality and intensity of emotional experiences that arise (Pekrun, 2006 , in Buric \& Soric, 2012). In this study, it appears that anxiety that arise in students are influenced by perceptions of their abilities in thesis work. The gap between personal or social standards and one's ability will lead to fear of failure, anxiety, which may lead to procrastination.

Action control is also known as self-efficacy (Bandura, 197), which is students' belief whether they are able to achieve desired outcome. Self-efficacy is a predictor for the emergence of anxiety during doing the thesis. This determines how much effort will be expended in doing thesis, which then has an impact on their behavior when working on thesis. Students with a high level of selfefficacy will decide to take an easier thesis activity that does not emerge anxiety, they will exert more effort in achieving their goals, and will persevere in facing various obstacles when working on thesis (Bandura, 1977, 1986). High expectations to achieve high results make students appraise their abilities that are not comparable with high personal and social expectations, will lead to anxiety (Lessin \& Pardo, 2017; Ashby \& Rice, 2002). Students with high self-efficacy will have logical thinking, be able to communicate, and be responsible for their duties therefore reducing anxiety while doing thesis. This will increase motivation in doing thesis.

\section{CONCLUSION}

Unpleasant emotions are influencing student procrastination in doing thesis article, that is anxiety. Anxiety during the process of working on thesis has a significant effect on the high procrastination of thesis work. The emergence of anxiety is influenced by cognitive appraisals, that is, action control (self-efficacy). These results suggest that reducing student procrastination in doing thesis, may be done with reducing anxiety by not expecting the high personal standards and increasing students' confidence in their ability while working thesis.

\section{REFERENCES}

[1] Buric, I., \& Soric, I. (2012). The Role of Test Hope and Hopelessness in Self-Regulated Learning: Relations Between Volitional Strategies, Cognitive Appraisals and Academic Achievement. Learning and Individual Differences, 22, 523-529.

[2] Cahyadi, S. (2013). Model Prestasi dalam Pengerjaan Skripsi Terkait dengan Peran Achievement Emotion dan Self-Regulation pada Mahasiswa Psikologi di Bandung (Unpublished doctor's dissertation). Universitas Padjadjaran, Bandung, Indonesia.

[3] Cerino, Eric S. (2014). Relationships between Academic Motivation, Self-Efficacy, and Academic Procrastination. The International honor society in psychology, Vol. 19, No.4/ISSN 2164-8204.

[4] Christensen, L. B., Johnson, R., \& Turner, L. A. (2011). Research Methods, Design, and Analysis $11^{\text {th }}$ Edition. USA: Pearson Education, Inc.

[5] Drysdale, Maureen T. B., \& McBeath, M. (2014). Exploring hope, self-efficacy, procrastination, and study skills between cooperative and non-cooperative education students. AsiaPacific Journal of Cooperation Education, 15(1), 69-79).

[6] Kandemir, Mehmet. (2014). Reasons of academic procrastination: self-regulation, academic self-efficacy, life satisfaction and demographics variables. Procedia - Social and Behavioral Sciences 152, 188-193. Elsevier Ltd.

[7] Kiamarsi, A., \& Abolghasemi, A. (2014). The relationship of procrastination and self-efficacy with psychological vulnerability in students. Procedia - Social and Behavioral Sciences 114, 858862

[8] Kutovic, A., Vrdoljak, G., \& Idzanovic, A. (2019). Predicting Procrastination: The Role of Academic Achievement, Selfefficacy and Perfectionism. International Journal of Educational Psychology, 8(1),1-26.

[9] Malkoc, A., \& Mutlu, Aynur K. (2018). Academic Self-efficacy and Academic Procrastination: Exploring the Mediating Role of Academic Motivation in Turkish University Students. Universal Journal of Educational Research 6 (10): 2087-2093.

[10] Murayama, K., Pekrun, R., Lichtenfeld, S., \& Hofe, R. (2012). Predicting Long-Term Growth in Students' Mathematics Achievement: The Unique Contributions of Motivation and Cognitive Strategies. Child Development Perspective, 84(4), 1475-1490.

[11] Pekrun, R., Goetz, T., Titz, W., \& Perry, R.P. (2002). Academic Emotions in Students' Self-Regulated Learning and Achievement: A Program of Qualitative and Quantitative Research, Educational Psychologist 37, 91-106.

[12] Pekrun, R. (2006). The Control-Value Theory of Achievement Emotions: Assumptions, Corollaries, and Implications for Educational Research and Practice. Educational Psychology Review, 18(4), 315-341.

[13] Pekrun, R., \& Schutz, P. A. (2007a). Emotion in Education. San Diego, CA: Academic Press.

[14] Pekrun, R., \& Linnenbrink-Garcia, L. (Eds). (2014). International Handbook of Emotions in Education. New York: Francis \& Taylor/Routledge.

[15] Schouwenburg, Henri C. (1995). Academic procrastination: Theoretical notions, measurement, and research. In J. R. Ferrari, Procrastination and Task Avoidance, 71-96. New York: Plenum Press.

[16] Universitas Padjadjaran. 2011. Pedoman Penyusunan dan Penulisan Skripsi Program Sarjana Universitas Padjadjaran. Bandung: Universitas Padjadjaran.

[17] Weiner, B. (1985). An Attributional Theory of Achievement Motivation and Emotion. Psychological Review, 92(4), 548-573. 